\title{
Alat Monitoring Radiasi Matahari di Pulau Batam
}

\author{
Muhammad Prihadi Eko Wahyudi ${ }^{1 *}$, Faiz Al Qodri', Maryani Septiana ${ }^{2}$, Qoriatul Fitriyah ${ }^{1}$ \\ ${ }^{1}$ Teknik Elektro, Politeknik Negeri Batam, Batam, Indonesia \\ ${ }^{2}$ Manajemen Bisnis, Politeknik Negeri Batam, Batam, Indonesia \\ *Email: prihadieko@polibatam.ac.id
}

\begin{abstract}
Abstrak-Photovoltaics (PV) cell adalah sebuah elemen yang dapat melakukan konversi energi dari radiasi akibat panas matahari menjadi energi listrik dengan prinsip semikonduktor. Tegangan dan arus listrik yang dihasilkan sel surya dipengaruhi oleh tingkat intensitas radiasi cahaya matahari dan temperatur udara lingkungan. Alat yang dibuat dalam penelitian ini didesain dengan menggunakan metode lookup table yang dibuat dengan memakai 2 motor sebagai penggerak sumbu $x$ dan $y$ dalam menentukan koordinat dari posisi matahari yang digunakan sebagai penentu intensitas radiasi matahari di Pulau Batam. Perangkat ini juga terintegrasi dengan waktu menggunakan real time clock module.
\end{abstract}

Kata kunci: Radiasi matahari, solar tracker, lookup table, modul real time clock, Perrin de Brichambaut

\section{PENDAHULUAN}

RADIASI dari energi matahari yang bisa ditangkap secara langsung dan tegak lurus melalui sinar matahari, berkisar pada nilai $1.368 \mathrm{Watt} / \mathrm{m}^{2}$. Akan tetapi, pada berbagai jenis kondisi di bumi, terutama berkaitan dengan halangan seperti atmosfer, maka pada saat matahari berada pada posisi puncaknya, energi yang bisa diterima oleh solar PV hanya mencapai $1000 \mathrm{~W} / \mathrm{m}^{2}$ saja [1].

Menurut Surya Negara (2016), wilayah Indonesia memiliki rerata intensitas radiasi harian matahari sebesar $4,8 \mathrm{~kW} / \mathrm{m}^{2}$ per harinya [2]. Ini berarti, potensi tersebut setara dengan 675 Watt-hour (Wh) per-hari yang akan dihasilkan oleh modul PV dengan kapasitas daya sebesar 100 Watt-peak (Wp) dan luas area solar cell sebesar $1 \mathrm{~m}^{2}$ [3]. Posisi Pulau Batam sendiri berada pada $01^{\circ} 08^{\prime} \mathrm{LU} 104^{\circ} 00^{\prime} \mathrm{BT}$. Ini berarti bahwa Batam memiliki selisih lintang satu derajat saja dari garis khatulistiwa. Dengan kata lain, data intensitas matahari di Pulau Batam akan mewakili mean radiasi sinar matahari secara umum untuk Indonesia.

Untuk memenuhi kebutuhan tersebut, perangkat dan sistem monitoring radiasi sinar matahari akan dirancang agar dapat melakukan monitoring pada beberapa hotspot area di Batam. Alat ini bekerja mula-mula dengan mengumpulkan radiasi sinar matahari menggunakan perangkat solar PV. Daya yang dihasilkan oleh perangkat ini kemudian diproses dan dianalisis dengan beberapa metode, salah satunya adalah metode Perrin de Brichambaut. Output data akan ditunjukkan dalam satuan Radian. Selain itu, untuk mengoptimalkan pengukuran, piranti PV akan menggunakan sistem tracking, dimana alat akan mengikuti arah pergeseran matahari berdasarkan perubahan waktu.

\section{TINJAUAN PUSTAKA}

Rata-rata intensitas matahari di Indonesia mencapai 4,8 $\mathrm{kWh} / \mathrm{m}^{2} /$ hari [2]. Adapun jangka waktu paparan sinar secara efektif adalah sebanyak 5 jam dalam kurun waktu 24 jam atau 1 hari [4].

Batam merupakan kota yang berada di Provinsi Kepulauan Riau dengan luas area sebesar $969 \mathrm{~km}^{2}$ dan terdiri atas 8 kecamatan, termasuk Kecamatan Belakang Padang, Bulang dan Galang. Pulau Batam sendiri, di luar tiga kecamatan tersebut, memiliki luas wilayah 421,2 $\mathrm{km}^{2}$ [5]. Berdasarkan data ini, apabila seluruh wilayah di Pulau Batam dipasang PV, maka potensi energi listrik yang bisa dihasilkan adalah sebesar (1):

$$
\begin{aligned}
& P=4,8 \frac{\mathrm{kW}}{\mathrm{m}^{2}} \times 421,2 \times 10^{6} \mathrm{~m}^{2} \\
& =2,02 \times 10^{6} \mathrm{MW}
\end{aligned}
$$

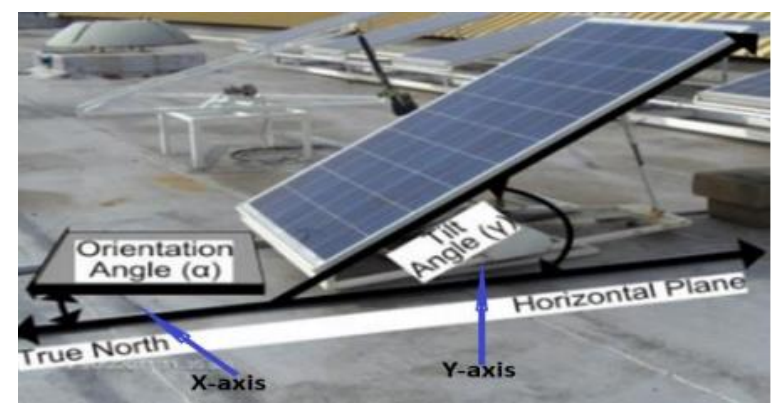

Gambar 1. Tilt angle dari solar tracking [6]

Metode Perrin de Brichambaut menunjukkan radiasi energi matahari dengan kemiringan $(\beta)$ yang terdiri atas radiasi dan 
radiasi difusi, dengan reflektivitas yang tergantung pada albedo tanah [7]-[11].

Pada solar tracking, sudut penyalaan (tilt angle) menunjukkan sudut di antara permukaan modul dengan bidang datar (horisontal) yang disebut sumbu $x$. Jika sudut ini diatur secara terus-menerus, daya optimal yang dihasilkan oleh solar PV bisa diraih [12]. Contoh sudut penyalaan bisa dilihat melalui Gambar 1.

\section{METODOLOGI}

\section{A. Perancangan Desain Mekanik}

Sistem tracking posisi matahari menggunakan metode lookup table yang akan dibuat adalah dengan memakai 2 motor sebagai penggerak sumbu $x$ dan $y$ dalam menentukan koordinat dari posisi matahari. Perangkat dapat terintegrasi dengan waktu menggunakan modul real time clock. Desain rancangan diperlihatkan pada Gambar 2.
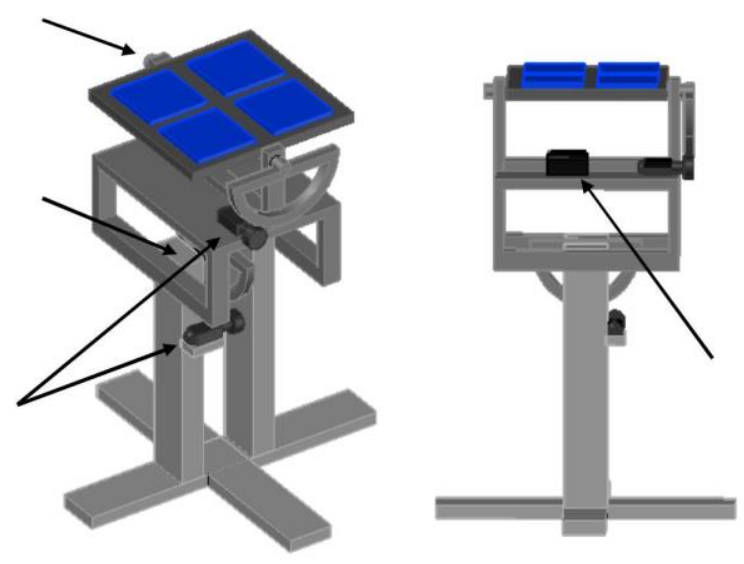

Gambar 2. Desain mekanik alat

\section{B. Perancangan Desain Elektrik}

Sistem tracking posisi matahari terdiri atas beberapa komponen yang diintegritaskan pada suatu mikrokontroler. Mikrokontroler berfungsi sebagai pusat pengolahan data secara terprogram dengan algoritma yang ditentukan. Mikrokontroler ini akan memberikan instruksi kepada komponen yang lain sesuai dengan fungsinya. Rancangan wiring diagram dari sistem tracking posisi matahari dapat dilihat pada Gambar 3.

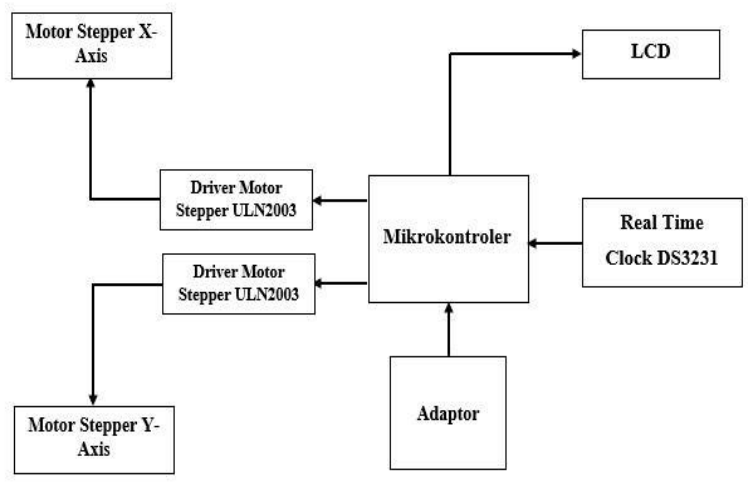

Gambar 3. Desain elektrikal

\section{HASIL DAN ANALISIS}

Tahapan penelitian dilakukan terlebih dahulu dengan pembuatan hardware alat dengan sistem pengelasan dan gerindra (Gambar 4). Setelah pengerjaan mekanik selesai dilakukan, instalasi alat dengan Arduino dilakukan seperti pada Gambar 5.

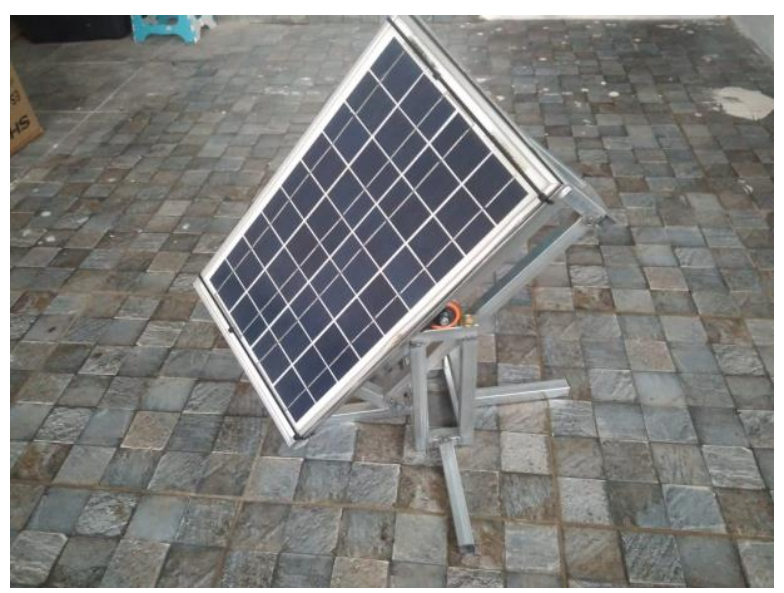

Gambar 4. Hasil Pengerjaan Mekanik Alat

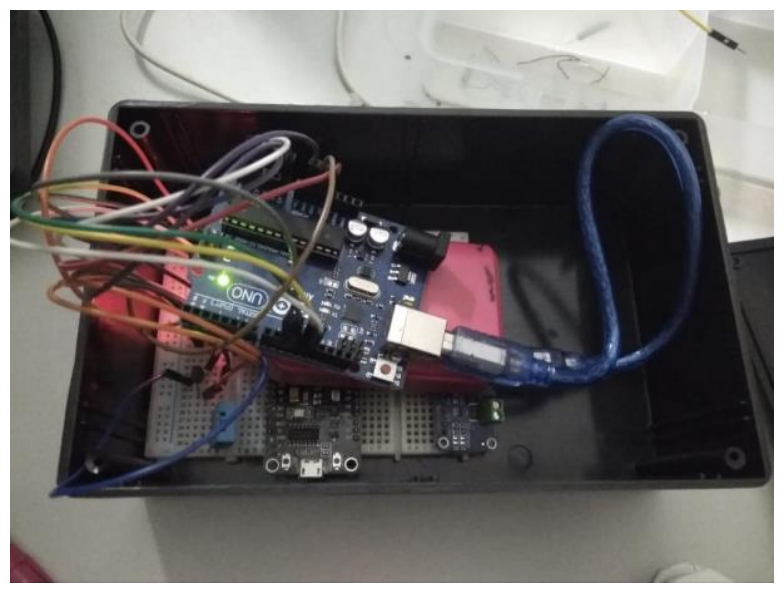

Gambar 5. Pengerjaan elektrikal alat

Berdasarkan pengujian yang dilakukan, output daya mendapatkan angka terbesar yaitu sebesar 6,138 Watt pada sore hari, sesuai dengan grafik pada Gambar 6 .

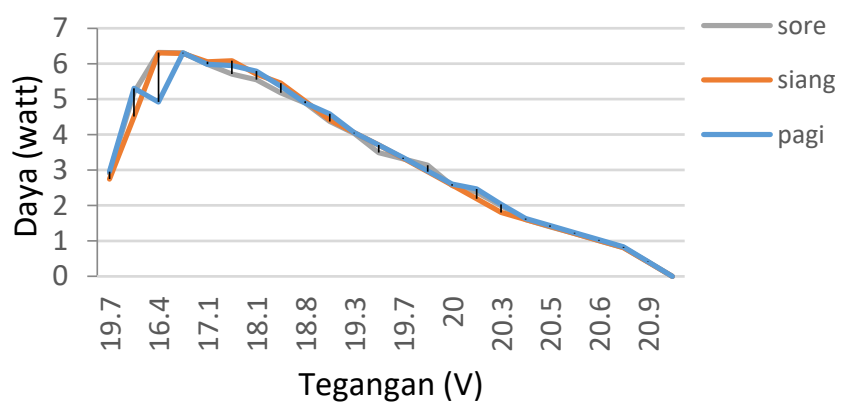

Gambar 6. Data pengukuran V-W dengan lookup table 


\section{KESIMPULAN}

Penelitian ini telah berhasil mencapai target yang diinginkan yaitu penyusunan, perakitan, serta ujicoba alat beserta pencatatan data radiasi sinar matahari yang diinginkan menggunakan metode lookup table. Pada penelitian ini, pengukuran terbatas hanya pada satu titik yaitu di Gedung W7 Politeknik Negeri Batam, sehingga data radiasi yang didapatkan masih terbatas hanya untuk lingkup area tersebut.

\section{UCAPAN TERIMA KASIH}

Ucapan terima kasih terutama ditujukan kepada P2M Politeknik Negeri Batam atas support berupa bantuan dana penelitian dosen muda 2019 beserta rekan dosen dan laboran RPE di Gedung W7 Politeknik Negeri Batam atas semua dukungannya.

\section{REFERENSI}

[1] "Solar Energy Perspectives - Analysis - IEA." [Online]. Available: https://www.iea.org/reports/solar-energy-perspectives. [Accessed: 26-Feb-2020].

[2] I. B. K. S. Negara, I. W. A. Wijaya, and A. A. G. M. Pemayun, "Analisis Perbandingan Output Daya Listrik Panel Surya Sistem Tracking dengan Solar Reflector," J. Ilm. Spektrum, vol. 3, no. 1, pp. 7-13, 2016.

[3] K. Akhmad, "Pembangkit Listrik Tenaga Surya Dan Penerapannya Untuk Daerah Terpencil," J. Ilm. Din. Rekayasa, vol. 1, no. 1, pp. 2933, 2005.

[4] B. Yuliarto, Memanen Energi Matahari. Bandung: Penerbit ITB, 2017.

[5] "Profil Kota Batam." [Online]. Available: http://ciptakarya.pu.go.id/profil/profil/barat/kep_riau/batam.pdf.

[6] T. Juhana and A. I. Irawan, "Non-intrusive load monitoring using Bluetooth Low Energy," in Proceeding of the 2015 9th International Conference on Telecommunication Systems Services and Applications, TSSA 2015, 2016.

[7] M. Ghodbane and B. Boumeddane, "Estimating solar radiation according to semi empirical approach of PERRIN DE BRICHAMBAUT: application on several areas with different climate in Algeria," Int. J. Energ., vol. 1, no. 1, pp. 20-29, 2016.

[8] S. A. Kalogirou, Solar Energy Engineering: Processes and Systems, 1st ed. Academic Press, 2009.

[9] A. Rabl, Active Solar Collectors and Their Applications. Oxford: Oxford University Press, 1985.

[10] Z. Şen, Solar energy fundamentals and modeling techniques: Atmosphere, environment, climate change and renewable energy. 2008.

[11] D. Y. Goswami, F. Kreith, and F. Kreith, "Solar Energy Resources," pp. 81-90, Jul. 2007.

[12] M. Lehloka, J. Swart, and P. Hertzog, "A comparison of two automatic solar tracking algorithms," E3S Web Conf., vol. 152, p. 02009, 2020. 